\title{
MEASURING SHADOWS
}




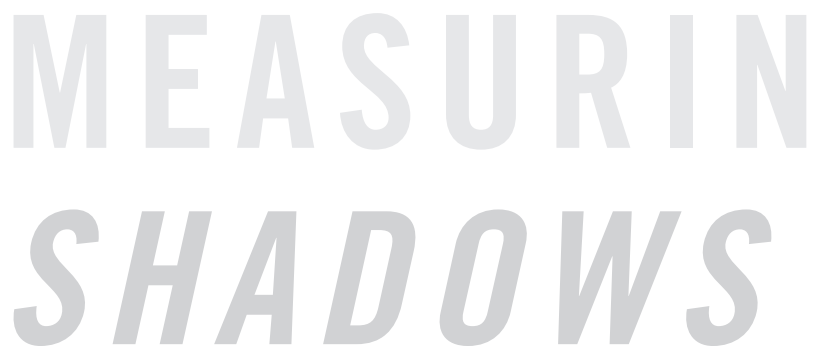

KE P LER'S OP T I C S OF INVISIB IL IT Y

RAZ CHEN-MORRIS 
Library of Congress Cataloging-in-

Publication Data

Chen-Morris, Raz, author.

Measuring shadows : Kepler's optics of invisibility / Raz Chen-Morris.

pages $\quad \mathrm{cm}$

Summary: "Focusing on the astronomer

Johannes Kepler's 1604 treatise on optics,

explores Kepler's radical break from scientific

and epistemological traditions and shows

how he posited new ways to view scientific

truth and knowledge in the early modern

period"-Provided by publisher.

Includes bibliographical references and index.

ISBN 978-0-271-07098-8 (cloth : alk. paper)

1. Kepler, Johannes, 1571-1630. Ad

Vitellionem paralipomena quibus astrono-

miae pars optica traditur.

2. Geometrical optics-History.

3. Science, Renaissance.

4. Science-Philosophy-History-17th

century.

I. Title.

QC $380 . K_{4} 6332016$

$535^{\circ} \cdot 32-\mathrm{dc} 23$

2015030525

Copyright $\odot 2016$ The Pennsylvania State University

All rights reserved

Printed in the United States of America

Published by

The Pennsylvania State University Press,

University Park, PA 16802-1003

The Pennsylvania State University Press is a member of the Association of American University Presses.

It is the policy of The Pennsylvania State University Press to use acid-free paper. Publications on uncoated stock satisfy the minimum requirements of American National Standard for Information SciencesPermanence of Paper for Printed Library Material, ANSI Z39.48-1992.

This book is printed on paper that contains $30 \%$ post-consumer waste. 
TO JOANNA 
He brushed away the thunder, then the clouds,

Then the colossal illusion of heaven. Yet still

The sky was blue. He wanted imperceptible air.

He wanted to see. He wanted the eye to see

And not be touched by blue. He wanted to know.

—WALLACE STEVENS, "LANDSCAPE WITH BOAT" 


\section{CONTENTS}

viii List of Illustrations

ix Acknowledgments

1 INTRODUCTION

24 One. The New Optical Narrative: Light, Camera Obscura, and the Astronomer's Wings

48 Two. "Seeing with My Own Eyes": Introducing the New Foundations of Scientific Knowledge

63 THREE. The Content of Kepler's Visual Language: Abstraction, Representation, and Recognition

97 FOUR."Non tanquam Pictor, sed tanquam Mathematicus": Kepler's Pictures and the Art of Painting

123 FIVE. Reading the Book of Nature: Allegories, Emblems, and Geometrical Diagrams

159 SIX. Nothing and the Ends of Renaissance Science

186 POSTSCRIPT

191 Notes

216 Bibliography

235 Index 